\title{
The Cultivation of Junior Middle School Students' Problem Awareness under the Background of Mathematics Core Literacy
}

Xiujuan Hua: School of Mathematical Sciences, University of Jinan, Jinan, Shandong 250022, P R China.

Yige Zhao: School of Mathematical Sciences, University of Jinan, Jinan, Shandong 250022, P R China.

*Shurong Sun: School of Mathematical Sciences, University of Jinan, Jinan, Shandong 250022, P R China.

Zhenlai Han: School of Mathematical Sciences, University of Jinan, Jinan, Shandong 250022, P R China.

ABSTRACT: Learning from thinking, thinking from doubt, People's thinking begins with problems, and they think only when they have problems. As a hot spot of educational research nowadays, the core accomplishment of mathematics leads the new direction of educational reform, puts forward higher requirements for solving mathematical problems, and pays more attention to cultivating students to solve mathematical problems with the thinking of core literacy of mathematics. Through discussing the meaning of mathematics core accomplishment and the recognition of "problem solving" under the background of mathematics core accomplishment, this paper discusses three methods of cultivating students' problem consciousness: creating situation, arousing problem consciousness, making students want to ask questions; The democratic atmosphere, the cultivation self-confidence, causes the student dares to ask; the positive appraisal, the body Test the sense of achievement, make the students happy to ask, so as to arouse teachers pay attention to cultivating students' problem awareness and ability, and stimulate students' creative thinking.

Key words: Problem, Junior high school students, Mathematics core accomplishment, Mathematics problem consciousness.

International Journal of Educational Studies Vol. 1, No. 1, pp. 8-11

2018

DOI: $10.53935 / 2641-533 x$ vlil.15

Corresponding Author: Shurong Sun Email: sshrong@163.com Funding: This study received no specific financial support.

Acknowledgment: This paper is the stage achievement of Jinan University Graduate Education Innovation Project "Research on Evaluation Criteria and System of Graduate Elucation Quality for Professional Deg Education Quality for Professional Degrees in Shandong Province under the Background of "Double-first-class "Construction" (No JDY1601) and "Research on Construction and Implementation of Quality Guarantee System for Graduate Education of Master of Education " (No. JDY1707).

Article History:

Received: 24 September 2018

Revised: 17 October 2018

Accepted: 12 November 2018

Published: 5 December 2018

(C) 2018 by the authors; licensee Academic

Publishing Group

\section{Introduction}

Mathematics itself is a subject with strong logic.In the Mathematics Curriculum Standard for compulsory Education(2011),it is mentioned that:"in the mathematics curriculum,we should pay attention to the development of students' sense of number,consciousness of symbols, concept of space, intuitive geometry, and concept of data analysis." Operational ability, reasoning ability and model thinking.Special attention should also be paid to the development of students' awareness of application and innovation." The ten articles are explained and explained one by one.In the interpretation of Standard(Experimental draft), the first six articles proposed in 2001 are called "core words" and then "core concepts".Ma Yunpeng(2015) thinks"Core words"or"Core",the concept"is not an exact expression,so in"several questions about the Core Literacy of Mathematics",these 10 terms are called"the Core Literacy of Mathematics" (Huang Huijuan and Wang Xi 2013)."the core accomplishment of mathematics"contains not only mathematical knowledge and skills, but also mathematical ability and thought,which can reflect the essence of these ten contents.The core 
accomplishment of mathematics is the essence of mathematics thought and comprehension formed by students in the course of learning mathematics.

\section{Re-Understanding of the Core Literacy of Mathematics}

The core accomplishment of mathematics is embodied in the following two aspects:first, from the external aspect, the person with mathematics literacy will separate the number of life,study and work, and then use the corresponding mathematical idea to solve a problem.Or to understand something (Qi, 2009).In other words, mathematics is everywhere,always with mathematical thinking and solve problems.Secondly, from the internal point of view, mathematics has the characteristics of objectivity,intuition, profundity and flexibility.Objectivity means that we study mathematics, the process of learning mathematics is mainly a process that reflects the objective world; intuitionism refers to the use of graphics,data,mold show Abstract mathematical thinking:profundity is the use of mathematical methods to help us reveal the deep nature and connection through the superficial phenomena of things; Flexibility refers to a mathematical problem, we can adopt a variety of ways, methods are flexible and diverse.

\section{Re-Understanding Of "Problem Solving" Under Core Literacy}

Under the background of quality-oriented education, the general goal of Mathematics Curriculum Standard of compulsory Education is to train students'ability to discover,propose, analyze and solve problems (Zhu Dejiang, 2004).Improving problem-solving ability is one of the aims of the basic education curriculum reform, is the request of the students' own development,helps to strengthen the students' creative consciousness and creative thinking, and helps the students to form a good cognitive structure.It helps to improve students' ability to learn independently.In the reform of the new mathematics curriculum,students' problem-solving ability is an important course goal that runs through the whole mathematics learning,and has been arousing heated discussion in the field of mathematics education.The change and Development of New Curriculum Reform and Standards The exhibition has made the relationship between mathematics core accomplishment and problem solving ability more and more close (Guillaume, 2007). As a new hot spot in mathematics education,the core accomplishment of mathematics has played an extremely important role in solving problems in mathematics quietly, which determines the students' ability to solve problems. At the same time, the core accomplishment of mathematics is also reflected in the whole process of students finding, proposing, analyzing and solving mathematical problems.

The transformation of ability concept, pay attention to improve student mathematics core accomplishment. The mathematics curriculum goal has experienced the process of "double base" goal and "three dimensional goal", now it has developed to the curriculum goal of mathematics core accomplishment (Zhao, 2006). Obviously, the traditional view of competence is no longer applicable, and the new view of core literacy in mathematics encourages students to be good at thinking, to think hard, and to apply what they have learned to the solution of practical problems. Only by cultivating the core accomplishment of mathematics can we improve the students' comprehensive quality of solving mathematical problems and promote the students' sustainable development.

International Journal of Educational Studies Vol. 1, No. 1, pp. 8-11

2018

DOI: 10.53935/2641-533x.v1i1.15

Corresponding Author: Shurong Sun

Email: sshrong@163.com

Funding: This study received no specific

financial support.

Acknowledgment: This paper is the stage achievement of Jinan University Graduate Education Innovation Project "Research on Evaluation Criteria and System of Graduate Evaluation Criteria and System of Graduate Education Quality for Professional Degrees in "Dhandong Province under the Background of "Double-first-class "Construction" (No JDY1601) and "Research on Construction and Implementation of Quality Guarantee System for Graduate Education of Master of Education" (No. JDY1707).

Article History

Received: 24 September 2018

Revised: 17 October 2018

Accepted: 12 November 2018

Published: 5 December 2018

(C) 2018 by the authors; licensee Academic

Publishing Group

\section{The Cultivation of Mathematical Problem Awareness of Junior Middle School Students} 4.1. Create Situations, Stimulate Awareness of Questions and Make Students Want To Ask Questions

The problem originates from the situation, the mathematical situation is the situation which contains the related mathematics knowledge and the mathematics thought method, at the same time is the background which the mathematics knowledge produces. It can not only stimulate the raising of mathematical problems, but also provide the corresponding information and data for the raising and solving of mathematical problems (Feng, 2016). Teachers should focus on designing situations in which students can discover and raise problems, rather than on the design problems themselves. The basic starting point of teaching should be to excavate the internal relationship between mathematical situations and mathematical problems. In particular, the situation of developing the core accomplishment of mathematics can arouse students' interest and enthusiasm, and the students' strong interest in learning is the student's. An inexhaustible force for progress.

Teachers should constantly encourage students to use their existing knowledge structure to understand, explain new phenomena and facts, stimulate students' impulse to ask questions in cognitive conflicts, and 


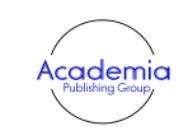

International Journal of Educational Studies Vol. 1, No. 1, pp. 8-11

2018

DOI: 10.53935/2641-533x.v1i1.15

Corresponding Author: Shurong Sun

Email: sshrong@163.com

Funding: This study received no specific

financial support.

Acknowledgment: This paper is the stage

achievement of Jinan University Graduate

Education Innovation Project "Research on

Evaluation Criteria and System of Graduate

Evaluation Criteria and System of Graduate

Education Quality for Professional Degrees in

Shandong Province under the Background of

"Double-first-class "Construction" (No

JDY1601) and "Research on Construction and Implementation of Quality Guarantee System for Graduate Education of Master of Education" (No. JDY1707).

Article History.

Received: 24 September 2018

Revised: 17 October 2018

Accepted: 12 November 2018

Published: 5 December 2018

(C) 2018 by the authors; licensee Academic

Publishing Group strengthen their awareness of problems (Liao, 2017). Sometimes teachers can leave loopholes in the classroom, make mistakes in the course of explanation, and make students question them.

In teaching, according to the students' age and psychological characteristics, we should create interesting, explorable and closely related real life situations for students, and create open problem situations with the goal of encouraging students to explore. Arousing students' positive and pleasant emotional activities, causing them to have the consciousness of revealing problems, and making them get mathematical experience of discovering and raising questions (Zhao, 2006). In addition, if the use of problem situations to raise mathematical problems as an important part of the examination, will cause students to put forward the problem of high attention, effectively stimulate students' awareness of the problem (Wang, 2017) .

\subsection{A Democratic Atmosphere That Builds Confidence and Enables Students to Ask Questions}

Students' emotions have a great influence on their intellectual activities. Harmonious and harmonious classroom atmosphere will make students' emotions in the best state and promote students' active thinking. Teachers should attach importance to the emotional factors that students ask questions, actively create a democratic and relaxed classroom atmosphere for students, so that students can form psychological freedom and psychological security in learning mathematics, and at the same time, they should adopt language and action. Expressions give students a kind of kind, trust, respect emotional message, make them feel that the teacher is the most reliable (Zhou, 2017).

It takes courage to ask questions. When students ask questions, teachers' eyes and expressions make students feel that teachers attach great importance to their own questions. Teachers should believe in the wisdom and ability of students and encourage students to make bold guesses and bold doubts. They should not only dare to raise questions that they do not understand and understand, but also dare to raise new puzzles and new problems arising from their own further thinking. Students should be encouraged to ask questions, discuss with each other, participate together, and fully develop the confidence to ask questions (Zhou, 2017). In the teaching process, when students are not satisfied with the teacher's explanation and have questions about the teacher's explanation, the teacher should give Affirmation and encouragement. Sometimes the questions raised by students are beyond the teachers' expectations, and even give the teachers problems. At this point, teachers should respect the students' spirit of questioning the problems and cherish the valuable enthusiasm of thinking. They should take advantage of the situation and create conditions. Helping students to explore problems not only protects students' initiative of independent thinking, questioning difficulties, but also encourages students' spirit of exploring the mysteries of knowledge (Liu, 2017).

\subsection{Positive Evaluation, Experience of Achievement, Make Students Happy To Ask}

In the practice of mathematics teaching, teachers need to make a timely comprehensive evaluation of students' classroom performance, and let students' mutual evaluation be used to evaluate students' learning in class. The various evaluation methods under the core accomplishment of mathematics are of great help in improving the teaching, improving the effect and enhancing the students' problem-solving ability. Therefore, teachers should pay more attention to the internalization of students' mathematics core accomplishment when applying teaching evaluation.

Even if the questions raised by students are odd, childish and even wrong, they should not be laughed at or criticized, and they should be explained and guided in good faith. For those students who are not good at asking questions and those who are weak and timid, once they ask questions, they should first be praised for their courage and then help them to analyze them. This will help them build up their self-confidence and arouse their enthusiasm. For those who ask but cannot grasp the key points, they should be guided patiently rather than ridiculed or sarcastically; for those who ask good questions, they should be encouraged to further explore, be bold and innovative, and let students taste the fun of questioning and stimulate the enthusiasm of questioning (Wang, 2017).

Due to the difference of students, the questions raised by students are not uniform, teachers should give priority to encouragement, but teachers should be value-oriented, so that students can know which problem is more valuable. In order to encourage the students to raise more and better questions, teachers should give full affirmation to the students who have creative consciousness, in order to encourage them to raise more and better questions and to create the sparks of the students' creative thinking. If they can be caught and displayed in time, they may have a profound impact on their creative work in life, and they will be encouraged to re- 


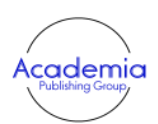

International Journal of Educational Studies Vol. 1, No. 1, pp. 8-11

2018

DOI: $10.53935 / 2641-533 x$ vlil.15

Corresponding Author: Shurong Su

Email: sshrong@163.com

Funding: This study received no specific

financial support.

Acknowledgment: This paper is the stage

achievement of Jinan University Graduate Education Innovation Project "Research on Evaluation Criteria and System of Graduate Evaluation Criteris Education Quality for Professional Degrees in Shandong Province under the Background of "Double-first-class "Construction" (No. JDY1601) and "Research on Construction and Implementation of Quality Guarantee System for Graduate Education of Master of Education" (No. JDY1707).

Article History:

Received: 24 September 2018

Revised: 17 October 2018

Accepted: 12 November 2018

Published: 5 December 2018

() 2018 by the authors; licensee Academic

Publishing Group create and rediscover. In mathematics teaching, we must take into account the state and performance of students in mathematics teaching, which is more beneficial to the cultivation of students. The core accomplishment of mathematics is helpful to improve the students' ability to solve problems.

\section{Conclusion}

The key is to inspire, guide, train and train the students. Letting students doubt themselves is more likely to stimulate creativity than to answer questions passively. To sum up, teachers should actively create democratic and open classroom teaching so that students can find their own problems and then produce learning needs. It is more important to correctly guide the students to raise their own questions, and finally to evaluate the students' problems positively, and to promote the internalization of the core accomplishment of mathematics.Only when there are problems can students have a direction of thinking. When they have the ability to ask questions, they can only dare to think. Only when we ask questions, be good at asking questions, can we develop our innovative consciousness and ability, and become a new generation of people who can find problems on their own initiative.

\section{References}

Huang Huijuan, \& Wang Xi. (2013). Definition and Evaluation of PISA: Mathematics Literacy. Shanghai Educational Research, 12: 3-5.

Qi Chunxia. (2009). Evaluation of International Mathematics Literacy and its Enlightenment to China. People's Education, 12: 7-8.

Zhu Dejiang. (2004). Elements and training Strategies of Primary School students' Mathematical Literacy. Subject Education, 7: 3-4.

Guillaume. (2007). How to cultivate students' problem consciousness in mathematics inquiry teaching. Teaching and Management, 6: 6.

Zhao Xiaoxiong. (2006). Cultivating students' problem consciousness in Mathematics Teaching. Mathematics Teaching Newsletter, 3: 4-5.

Feng DUI. (2016). A brief talk on how to cultivate students' problem Awareness in Junior Middle School Mathematics classroom Teaching. Literature and Science Navigation, 2: 6.

Liao Hongbo. (2017). On the cultivation of Middle School students' problem Awareness in Mathematics Teaching in Junior Middle School. Chinese youth, 36: 174

Wang Qingling. (2017). The training Strategy of Middle School students' problem Awareness in Mathematics Teaching in Senior Middle School. Mathematics Big World, 12: 8.

Zhou Dongliang. (2017). On the cultivation of Middle School students' problem Awareness in Mathematics Teaching in Junior Middle School. Mathematics Big World, 10: 90.

Liu Xiansheng. (2017). A brief talk on the training Strategy of Middle School students' problem Awareness in Mathematics Teaching in Primary School. New curriculum (middle), 7: 212.

Wang Qiyan. (2017). Be good at asking questions, be sensitive to activities, and be brave in innovation--On the cultivation of students' innovative consciousness in mathematics teaching in junior high school. Examination Weekly, 39: 86-87. 